\title{
Loud Music and Leisure Noise Is a Common Cause of Chronic Hearing Loss, Tinnitus and Hyperacusis
}

\author{
Martin Pienkowski
}

\author{
Osborne College of Audiology, Salus University, Elkins Park, PA 19027, USA; mpienkowski@salus.edu
}

\begin{abstract}
High sound levels capable of permanently damaging the ear are experienced not only in factories and war zones but in concert halls, nightclubs, sports stadiums, and many other leisure environments. This review summarizes evidence that loud music and other forms of "leisure noise" are common causes of noise-induced hearing loss, tinnitus, and hyperacusis, even if audiometric thresholds initially remain within clinically normal limits. Given the huge global burden of preventable noise-induced hearing loss, noise limits should be adopted in a much broader range of settings, and education to promote hearing conservation should be a higher public health priority.
\end{abstract}

Keywords: music; noise; hearing loss; tinnitus; hyperacusis

Citation: Pienkowski, M. Loud Music and Leisure Noise Is a Common Cause of Chronic Hearing Loss, Tinnitus and Hyperacusis. Int. J. Environ. Res. Public Health 2021, 18, 4236. https://doi.org/10.3390/ ijerph18084236

Academic Editors: Paul Tchounwou and Massimo Ralli

Received: 15 March 2021

Accepted: 14 April 2021

Published: 16 April 2021

Publisher's Note: MDPI stays neutral with regard to jurisdictional claims in published maps and institutional affiliations.

Copyright: (C) 2021 by the author. Licensee MDPI, Basel, Switzerland. This article is an open access article distributed under the terms and conditions of the Creative Commons Attribution (CC BY) license (https:// creativecommons.org/licenses/by/ $4.0 /)$.

\section{Introduction}

We operate noisy machines, fire guns, and turn up our music, exposing ourselves to high sound pressure levels (SPLs) with the potential to cause chronic hearing loss, tinnitus (phantom sensations of ringing or other noises in the ears or head), and hyperacusis (discomfort and in some cases long-lasting pain triggered by sound levels that most people can tolerate) [1-8]. The invention of the audiometer and sound level meter [9] enabled research that eventually led most countries, including the United States in the 1970s, to implement legal limits for exposure to workplace noise [10-17]. While these measures (summarized in Section 2) have helped, noise-induced hearing loss (NIHL) and its associated disorders remain the most common injuries in many industrial and military settings, contributing heavily to the huge global burden of hearing loss [18-34]. Regrettably, noise limits have rarely been enforced outside of traditional extraction and manufacturing industries [35]. As detailed in Section 3 of this review, exposure to loud music and other forms of "leisure noise" also commonly causes chronic NIHL, tinnitus, and hyperacusis.

That loud noise can permanently impair hearing and trigger tinnitus has been recognized since antiquity, as mentioned in the writings of Aristotle and Pliny the Elder (tinnitus is Latin for "ringing"). In one of the first issues of The Lancet, Fosbroke [36] wrote that the hearing loss of blacksmiths was "a consequence of their employment, occasioned by the noise of forging; it creeps on them gradually, in general at about forty or fifty years of age. At first, the patient is insensible of weak impressions of sound; the deafness increases with a ringing and noise in the ears ... ". Fosbroke was right that noise-induced losses of sensitivity to soft sounds can occur gradually, often becoming apparent only in middle age. However, permanent audiometric threshold shifts (PTS) are also commonly seen in noise-exposed adolescents and younger adults, particularly in the 3-6 kHz "noise notch" range and at the "extended high frequencies" (EHFs), above the $8 \mathrm{kHz}$ limit of conventional audiometry. Fosbroke was also right that tinnitus typically becomes more prevalent and bothersome as "the deafness increases" [37-39], but we now know that many people with noise-induced tinnitus, hyperacusis, and difficulties understanding speech, particularly in background noise, have normal or near-normal audiograms [40-53], and may not develop substantial PTS until later in life. Animal lab studies have shown that audiometry is not sensitive to the loss of as many as 30-40\% of cochlear outer hair cells [54-57] and 50-80\% of cochlear inner hair cells and nerve fibers [58-63]. Thus, considerable damage to the cochlea 
can accumulate before PTS becomes pronounced, giving rise to the notion of "hidden hearing loss" [64].

Unfortunately, music and noise levels loud enough to permanently damage the ear can for a time feel comfortable and even be addictingly enjoyable [65]. Chung et al. [66] polled a large number of American teenagers and young adults and found that about half had experienced temporary threshold shifts (TTS) and transient tinnitus after attending concerts or nightclubs. If at least some of these events can cause irreparable damage to some fraction of cochlear hair cells and nerve fibers in some individuals-even as audiometric thresholds initially recover, and tinnitus disappears - then enough damage could eventually accumulate with repeated exposures to cause more chronic hearing problems. Indeed, many people attribute the onset of their chronic tinnitus or hyperacusis to a specific loud music or noise dose that did not otherwise stand out from similar experiences in the past. As a young concert goer recently put it: "My tinnitus always went away, until it didn't. After about a year, I thought, this is permanent now. This is going to suck forever" [67].

\section{A Brief Summary of Occupational Noise Limits in the U.S.A.}

In 1972, the newly formed U.S. National Institute for Occupational Safety and Health $(\mathrm{NIOSH})$ recommended that workplace noise not exceed the time-weighted average (TWA) level of $85 \mathrm{~dB}(\mathrm{~A})$ over an $8 \mathrm{~h}$ workday and $40 \mathrm{~h}$ week [14] (The $\mathrm{dB}(\mathrm{A})$ scale is a filtered version of the $\mathrm{dB}$ SPL scale that compensates for our poorer ability to hear the very low frequencies generated by most noise sources). NIOSH suggested that an additional $3 \mathrm{~dB}$ over $85 \mathrm{~dB}(\mathrm{~A})$ be allowed for each halving of the daily noise dose from $8 \mathrm{~h}$ (Figure 1). This $3 \mathrm{~dB}$ "exchange" is based on the "equal energy hypothesis", which maintains that sound energy and exposure duration can be traded off, up to a point, to induce similar TTS. (Note that a doubling of the sound energy represents a $3 \mathrm{~dB}$ increase, and so the exposure duration is halved to keep sound energy equal.) For example, the NIOSH recommended exposure limit (REL) for a TWA level of $91 \mathrm{~dB}(\mathrm{~A})$ is $2 \mathrm{~h}$ daily and $10 \mathrm{~h}$ weekly.

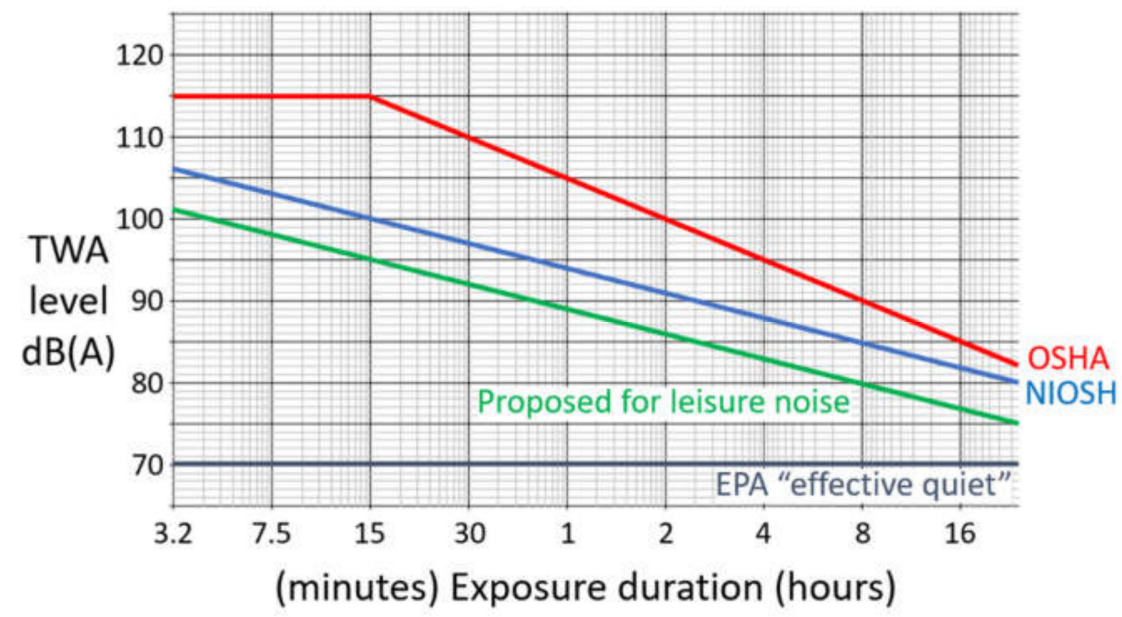

Figure 1. The U.S. National Institute for Occupational Safety and Health maximum time-weighted average (TWA) recommended exposure level (i.e., the NIOSH REL [14] in blue), and the U.S. Occupational Safety and Health Administration maximum TWA permitted exposure level (i.e., the OSHA PEL [16] in red), is plotted as a function of exposure duration. In addition, a recent recommendation for maximum TWA exposure levels for leisure noise $[68,69]$ is plotted (in green), along with the U.S. Environmental Protection Agency (EPA) "effective quiet" level of $\leq 70 \mathrm{~dB}(\mathrm{~A})$ [15].

NIOSH [14] explicitly stated that its guidelines would not safeguard all workers from NIHL. The agency defined "material hearing impairment" as a pure tone average (PTA) threshold exceeding $25 \mathrm{~dB}$ HL (hearing level) over the $1-4 \mathrm{kHz}$ frequency range and estimated that a 40-year working lifetime exposure at its REL would cause material 
impairment in $8 \%$ of workers. However, as mentioned above and substantiated below, people can develop tinnitus, hyperacusis, and difficulties understanding speech (especially in background noise) even if their audiogram remains better than $25 \mathrm{~dB}$ HL. Moreover, audiometric losses at frequencies above $4 \mathrm{kHz}$, also not included in the NIOSH definition of material hearing impairment, can by themselves affect sound localization and speech intelligibility [70,71]. Notably, NIOSH [14] cautioned that "a noise capable of causing significant TTS is probably capable of causing significant permanent losses in hearing, given prolonged or recurrent exposures" (Of course, if the noise levels are very high, as in an explosive blast, permanent NIHL can result from a single exposure).

To protect workers against any occupational NIHL — not just the majority of workers from NIOSH's material impairment-the U.S. Environmental Protection Agency (EPA) [15] derived the much lower $8 \mathrm{~h}$ exposure limit of $75 \mathrm{~dB}(\mathrm{~A})$. However, even this lower limit assumes that workers will not be exposed to additional loud noise from household chores and repairs, hobbies, urban environments, etc. The EPA asserted that sound levels up to $70 \mathrm{~dB}(\mathrm{~A})$ represent a safe "effective quiet" that poses little risk to people with normal hearing because they do not induce significant TTS [72-74]. Unfortunately, noise levels above $70 \mathrm{~dB}(\mathrm{~A})$ are common in everyday life, on city streets and subways [75-78], and loud music and noise exposure outside of work undoubtedly exacerbates the risk of occupational NIHL [79-85].

Despite the NIOSH and EPA recommendations, the U.S. Occupational Safety and Health Administration (OSHA) [16] enforces a substantially higher 8-hour exposure limit of $90 \mathrm{~dB}(\mathrm{~A})$, with a $5 \mathrm{~dB}$ exchange (Figure 1). This means, for example, that the OSHA permitted exposure limit (PEL) for a TWA level of $100 \mathrm{~dB}(\mathrm{~A})$ is $2 \mathrm{~h}$ daily, 8 times longer than the NIOSH REL of $15 \mathrm{~min}$. OSHA caps permitted noise levels at $115 \mathrm{~dB}(\mathrm{~A})$ for exposure durations of more than one second and at $140 \mathrm{~dB}$ pe (peak equivalent) SPL for very brief noise impulses. Although the OSHA PEL is $90 \mathrm{~dB}(\mathrm{~A})$, employers are legally required to take the following three actions when the 8-h TWA noise level exceeds 85 $\mathrm{dB}(\mathrm{A})$ : provide hearing protection devices, establish hearing conservation programs for workers that include education and training, and sponsor annual audiometric testing (up to $6 \mathrm{kHz}$ ). NIOSH [17] estimated that a lifetime exposure at the OSHA PEL would cause material impairment in $25 \%$ of workers, which is close to what epidemiological studies have found [26]. Similar exposure limits and directives have been adopted by the European Union and elsewhere [84-88].

\section{Loud Music and Leisure Noise Is a Common Cause of Permanent Hearing Loss, Tinnitus, and Hyperacusis}

Beach et al. [89] reported that $14 \%$ of a large sample of Australian young adults was exposed to an annual leisure noise dose that by itself exceeded the NIOSH REL (18\% of $18-24$-year-olds, $13 \%$ of $25-29$-year-olds, and $8 \%$ of $30-35$-year-olds). This puts the leisure noise problem in perspective. By far, the main culprits, representing $\sim 70 \%$ of the total noise energy, were nightclubs (Section 3 ii; see also [81,90]). Similar findings were reported in Michigan's Kalamazoo County [91]: 15\% of adult men and $8 \%$ of women were overexposed by NIOSH criteria to leisure noise alone. Even higher estimates of leisure noise over-exposure have been obtained for teenage and college student populations [81,92-100]. The World Health Organization (WHO) [101] recently cautioned that "1.1 billion young people worldwide could be at risk of hearing loss due to unsafe listening practices. Nearly half of all teenagers and young adults (12-35 years old) in middle- and high-income countries are exposed to unsafe levels of sound from the use of personal audio devices, and some $40 \%$ of them are exposed to potentially damaging sound levels at clubs, discotheques and bars". Below we discuss some common sources of loud music and leisure noise and document their effects on hearing. Note that the list is not exhaustive; many of our contraptions can generate sound levels that potentially (depending on the SPL, exposure duration, etc.) pose risks to unprotected ears (e.g., fireworks, power tools, lawn mowers, leaf blowers, hand driers, blenders, etc.). 


\subsection{Live Music Performances and Rehearsals}

Audiences at rock or pop concerts are routinely exposed for hours to average sound levels exceeding $100 \mathrm{~dB}(\mathrm{~A})$ [102-106]. Recall that the NIOSH REL for an exposure level of $100 \mathrm{~dB}(\mathrm{~A})$ is just $15 \mathrm{~min}$ per day, while the OSHA PEL is $2 \mathrm{~h}$ per day. For example, Gunderson et al. [105] found that TWA sound levels during rock concerts in eight New York City clubs ranged from 95 to $107 \mathrm{~dB}(\mathrm{~A})$. A majority of club employees $(17 / 31,55 \%)$ reported acquiring hearing problems on the job, while only $16 \%$ regularly wore earplugs. Gunderson et al. [105] concluded that "the development of hearing conservation programs for this large group of workers is essential". Meyer-Bisch [104] reported that young adults who attended at least one rock or pop concert per month had significantly poorer audiometric thresholds at frequencies $\geq 3 \mathrm{kHz}$ relative to age-matched controls and were five times more likely to report chronic hearing problems, such as tinnitus. In a sample of people with clinically normal audiograms in the conventional frequency range, more frequent concert-goers exhibited PTS in the EHFs above $8 \mathrm{kHz}$ [107]. Thus, elevated thresholds in the EHFs may be even earlier indicators of NIHL than 3-6 kHz noise notches, a finding corroborated by many other studies reviewed below. Opperman et al. [106] also measured a range of 95 to $107 \mathrm{~dB}(\mathrm{~A})$ during three rock/pop performances in a popular Minnesotan concert hall. Patrons who did not use earplugs developed an average TTS $_{2}$ (measured immediately after exposure) of $10 \mathrm{~dB}$ from 3 to $6 \mathrm{kHz}$, but this varied widely $(\mathrm{SD}=10 \mathrm{~dB}$; see also [108]), whereas the small minority of patrons who did wear earplugs did not develop significant TTS. Bogoch et al. [109] reported that $85 \%$ of a rock concert audience experienced transient tinnitus after the show, while only $20 \%$ wore earplugs.

Axelsson and Lindgren [110] found that almost half $(46 \%, 38 / 83)$ of surveyed Swedish professional rock/pop musicians exhibited some PTS in the conventional frequency range (threshold $\geq 20 \mathrm{~dB}$ HL at least at one frequency). In a follow-up study of the same musicians 16 years later, Axelsson et al. [111] reported that their hearing loss had become worse compared to age-matched controls, especially at 4 and $8 \mathrm{kHz}$. Similar results on a different sample of 139 Swedish professional rock/pop/jazz musicians were published by Kähäri et al. [112]: 49\% had a PTS in the conventional frequency range (using the more stringent criterion of $\geq 25 \mathrm{~dB}$ HL at two frequencies, or $\geq 30 \mathrm{~dB}$ HL at one frequency), and $74 \%$ reported tinnitus, hyperacusis, and/or diplacusis (the perception that a single sound has a different pitch in the two ears). Juman et al. [113] found that noise-induced audiometric losses in steelpan drummers tended to emerge slowly, becoming significant relative to age-matched controls only after age 40 . Nevertheless, two-thirds of drummers who played for $>20$ years developed significant PTS, as did $40 \%$ of drummers who played for 10-20 years [113]. Schmuziger et al. [114] found that a sample of 42 amateur rock/pop musicians, drummers, in particular, had poorer than expected thresholds at $3-8 \mathrm{kHz} ; 26 \%$ were diagnosed with hyperacusis and $17 \%$ with tinnitus. Størmer et al. [115] also noted that Norwegian rock musicians had a PTS at $3-8 \mathrm{kHz}$ compared to controls, and $20 \%$ had chronic tinnitus. Mcllvaine et al. [116] had members of a rock band wear personal dosimeters during a typical $2 \mathrm{~h}$ rehearsal and $4 \mathrm{~h}$ performance. The rehearsal exceeded the NIOSH REL but fell within the OSHA PEL, while the performance exceeded even the OSHA PEL, underscoring the risks of performances in particular to rock musicians' hearing.

Average sound levels in a symphony orchestra pit also typically exceed $85 \mathrm{~dB}(\mathrm{~A})$ during rehearsals and performances [117-121]. While orchestral musicians do not play together for $40 \mathrm{~h}$ per week year-round, about $50 \%$ exceed the weekly NIOSH REL during solitary practice alone [122]. Nevertheless, one early study of Swedish orchestra musicians by Karlsson et al. [123] reported no evidence of NIHL and concluded that "sound exposure criteria for industrial noise are not valid when discussing such sounds as are produced by acoustic instruments in a symphonic environment". In support of this conclusion, Strasser et al. [124] found that exposure to $2 \mathrm{~h}$ of classical music at an average level of $91 \mathrm{~dB}(\mathrm{~A})$ (the NIOSH REL) induced much less TTS ( $10 \mathrm{~dB})$ than the equivalent dose of industrial noise $(\sim 25 \mathrm{~dB})$ in the same subjects. Strasser et al. [125] had earlier shown that there was no such difference between industrial noise and heavy metal music. Classical music 
is typically more spectrotemporally modulated than heavy metal music and industrial noise, and perhaps the emotional response to classical music also has some otoprotective effect [126].

Even if loud classical music poses a lower risk of NIHL than a similar dose of heavy metal music or industrial noise, the negative result of Karlsson et al. [123] has been overturned by many subsequent studies [118,120,127-140]. For example, Royster et al. [118] found that Chicago Symphony Orchestra musicians were exposed at just above the NIOSH REL during their $15 \mathrm{~h}$ of weekly rehearsals and performances (not counting solitary practice). About half of these Chicago musicians $(53 \%, 31 / 59)$ had audiometric notches at 3-6 kHz, and violinists and violists had poorer 3-6 kHz thresholds in their left compared to right ears, consistent with the left ear receiving greater exposure from their instruments [118]. Noise notches were also found in musicians employed at the Gothenburg Symphony Orchestra and the Gothenburg Opera in Sweden [130,131], and in 45\% (149/329) of American college student classical musicians [134]. Student musicians with normal audiograms (no noise notches) in the conventional frequency range nevertheless had poorer EHF thresholds compared to controls [141,142] (but see [143] for a negative finding), reported more loudness tolerance problems (i.e., hyperacusis), and exhibited poorer speech intelligibility in noise [142]. A study of average sound levels associated with high school and university marching bands, which are especially popular in the U.S.A., reported a range of $95-122 \mathrm{~dB}(\mathrm{~A})$ for drum sections and 106-118 $\mathrm{dB}(\mathrm{A})$ for cymbal sections, both greatly exceeding the NIOSH REL [144] (see also $[145,146])$. However, the only audiometric study on university marching band members that I could find failed to detect evidence of PTS in the conventional frequency range [147].

Clark [103] measured average sound levels below $90 \mathrm{~dB}(\mathrm{~A})$ in the audience of classical music concerts, remarking: "Given that even the most enthusiastic concert-goer most likely could not exceed $20 \mathrm{~h}$ per week of exposure, it is unlikely that attending classical music concerts poses any risk of NIHL for anyone". However, Clark [103] noted that audiences of big jazz ensembles could be exposed to potentially more threatening levels, averaging around $95 \mathrm{~dB}(\mathrm{~A})$.

In a meta-analysis of 41 studies counting 4618 professional musicians, Di Stadio et al. [148] reported that $64 \%$ of rock/pop musicians had at least some audiometric loss, compared to $33 \%$ of classical musicians. The prevalence of chronic tinnitus was $26 \%$ in both rock/pop and classical musicians, while that of hyperacusis was $27 \%$ in rock/pop musicians and $19 \%$ in classical musicians [148]. Many high-profile rock/pop musicians have come forward with sad personal stories and warnings about NIHL, tinnitus, and hyperacusis [149]. In a recent landmark legal case, London's Royal Opera House was successfully sued by a violist who was exposed to peak levels of $132 \mathrm{~dB}(\mathrm{~A})$ during a rehearsal of Wagner's Die Walkure and afterward began to suffer from debilitating tinnitus and hyperacusis [150]. The Opera House appealed the verdict, claiming that the artistic value of the music meant that some hearing damage to its performers was inevitable and justifiable, but this was rejected by the Court of Appeal, which maintained that the orchestra pit should be subject to the same noise regulations as a factory floor.

\subsection{Discotheques and Nightclubs}

Tan et al. [151] recorded sound levels in 20 Hong Kong discos and reported a grand average of $95 \mathrm{~dB}(\mathrm{~A})$ that was quite consistent across venues. Employees of these discos typically worked more than $50 \mathrm{~h}$ per week and so were exposed at substantially above the NIOSH REL [151]. Similarly, high sound levels were subsequently recorded in nightclubs in Singapore [152], the U.K. [153], South Korea [154], the U.S.A. [155], Germany [156], and Ireland [157].

Potier et al. [158] studied the hearing of 29 young professional disc jockeys (DJs) who worked in French clubs for an average of 6 years. In addition to the usual 3-6 kHz noise notch, they tended to have hearing loss at frequencies below $1 \mathrm{kHz}$ (likely from cranking the bass), and 76\% reported chronic tinnitus. In an important 4-year longitudinal 
study, Argentinian teenagers who occasionally attended discos developed PTS at 14 and $16 \mathrm{kHz}$ to a greater extent than at 4 and $6 \mathrm{kHz}[93,159-161]$, again suggesting that hearing sensitivity at the EHFs is most vulnerable to noise trauma. Johnson et al. [98] surveyed 325 British university students and reported that $88 \%$ experienced tinnitus after leaving a nightclub, and $66 \%$ still noticed TTS the following morning. Although over $70 \%$ felt that nightclub noise should be limited to safe levels, a similar percentage claimed that they would continue attending clubs despite knowing the risks of NIHL.

\subsection{Personal Listening Devices}

Billions of people of all ages listen to music via earphones paired to cell phones or other personal listening devices (PLDs). Some listen at dangerously high levels that can average well over $100 \mathrm{~dB}(\mathrm{~A})$ at maximum volume settings [162-164], which puts users at risk of NIHL [165].

Fligor et al. [166] found that 60 adult residents of boisterous New York City set their PLDs at the average level of $94 \mathrm{~dB}(\mathrm{~A}) ; 62 \%$ of them exceeded the daily NIOSH REL with PLD use alone. Similar numbers were reported in a larger sample of 189 New York City college students: $58 \%$ and $52 \%$, respectively, exceeded daily and weekly NIOSH limits through PLD use alone [167]. Such high music levels are typical when trying to drown out loud background noise [163]. In ostensibly quieter Australian environments, Gilliver et al. [168] reported that about 10\% of PLD users exceeded the NIOSH REL. For Israeli teens, that number was about $25 \%$ [169], while $44 \%$ of Canadian teens self-reported loud PLD use [81]. Primary school children also appear vulnerable to NIHL from PLD use, especially boys $[81,170,171]$ (see also [172,173] for other loud toys).

Peng et al. [174] found that Chinese university students who used PLDs had poorer audiometric thresholds above $3 \mathrm{kHz}$ compared to controls, with the greatest differences above $6 \mathrm{kHz}$. Additionally, PLD users with clinically normal audiograms to $8 \mathrm{kHz}$ had elevated EHF thresholds [174]. Le Prell et al. [175] also found elevated EHF thresholds in young American adults with clinically normal audiograms who reported long-term or high-volume PLD use. Elevated EHF thresholds despite normal conventional thresholds, as well as reduced transient evoked and distortion product otoacoustic emissions (TEOAEs and DPOAEs), were also found in a group of PLD users with otherwise unremarkable noise exposure histories by Sulaiman et al. [176].

\subsection{Non-Motorized Sports}

According to the Guinness Book of World Records, the loudest crowd roar recorded in a sports stadium reached $142 \mathrm{~dB}(\mathrm{~A})$ at an NFL (National Football League) game at Arrowhead Stadium in Kansas City, Missouri, on 29 September 2014. Engard et al. [177] had 28 workers and 25 fans wear personal dosimeters in medium and large college American football stadiums and NFL stadiums, with average game attendances of $\sim 20 \mathrm{~K}, 50 \mathrm{~K}$, and $75 \mathrm{~K}$, respectively. TWA noise levels were similar across games and stadiums despite the varied attendances, ranging from 91 to $95 \mathrm{~dB}(\mathrm{~A})$; almost all sampled workers and fans were overexposed by daily NIOSH criteria [177]. Engard et al. [177] concluded: "Facility managers should include a warning in fan guides, pamphlets, websites, or other appropriate communication tools of possible loud-noise exposure during any sporting events held at the stadiums. This information should include the health effects of loud noise exposure, namely, noise-induced hearing loss. The information also should be specifically targeted to parents of young children, including a strong recommendation that hearing protection should be worn by all children during the sporting event".

Hodgetts and Liu [178] recorded TWA levels of 101-104 dB(A) in Canadian hockey arenas during NHL (National Hockey League) playoff games, with peaks above $120 \mathrm{~dB}(\mathrm{~A})$. During collegiate and minor league professional hockey games in American arenas, average sound levels were almost $90 \mathrm{~dB}(\mathrm{~A})$ [179]. Swanepoel and Hall [180] reported that noise levels at a South African Premier Soccer League match averaged $100 \mathrm{~dB}(\mathrm{~A})$ and that spectators incurred TTS and DPOAE amplitude reductions measured after the match. The 
games of the 2010 FIFA (Federation Internationale de Football Association) World Cup, also held in South Africa, were even louder due to the prolific use of vuvuzelas, African horns which generate sound levels of about $130 \mathrm{~dB}(\mathrm{~A})$ at the horn opening. Flamme and Williams [181] found that Michigan sports officials had a greater prevalence of selfreported hearing difficulties, including tinnitus, than the general population; sound levels produced by whistles, which ranged from 104 to $116 \mathrm{~dB}(\mathrm{~A})$, were noted as potential contributing factors.

Torre and Howell [182] recorded average music levels of $87 \mathrm{~dB}(\mathrm{~A})$ during $50 \mathrm{~min}$ aerobics classes and found that these caused small but significant transient reductions in DPOAE amplitudes. Nassar [183] found that all participants in an aerobics class developed significant TTS after a $1 \mathrm{~h}$ exposure to $92 \mathrm{~dB}(\mathrm{~A})$. Beach and Nie [184] measured TWA levels of $93 \mathrm{~dB}(\mathrm{~A})$ in high-intensity aerobics classes and reported that only $20 \%$ of participants said that such loud music was stressful and that $85 \%$ of instructors considered it to be motivating.

\subsection{Motorized Sports and Hobbies}

Rose et al. [185] measured noise levels during a NASCAR (National Association for Stock Car Auto Racing) race and reported that they ranged from 99 to $109 \mathrm{~dB}(\mathrm{~A}) 20$ feet from the track and 96-104 $\mathrm{dB}(\mathrm{A}) 150$ feet from the track. In the pit area, peak levels exceeded the OSHA limit of $140 \mathrm{~dB}(\mathrm{~A})$ [185]. Kardous and Morata [186] found that race car drivers and pit crew members were exposed to noise well above the daily OSHA limit. Hearing protection use was variable and intermittent among team members [186]. Morley et al. [187] measured average sound levels of 95-100 dB(A) at monster truck and motocross shows. McCombe and Binnington [188] surveyed 44 young motorcycle Grand Prix racers and found $45 \%$ had some audiometric loss, while only nine riders (20\%) were regular earplug users.

Ross [189] measured noise levels inside five models of full-face motorcycle helmets at a riding speed of $60 \mathrm{mph}$ and reported a range of $95-103 \mathrm{~dB}(\mathrm{~A})$, with a spectral peak between 250 and $500 \mathrm{~Hz}$ (see also [190]). McCombe et al. [191] obtained audiograms from 246 motorcyclists with otherwise unremarkable noise exposure histories and found that they had hearing loss predominantly at 500 and $1000 \mathrm{~Hz}$, as expected from the helmet noise spectrum. Moore [192] measured in-helmet noise levels for 10 recreational snowmobilers during rides averaging a distance of about 50 miles and found that all riders exceeded the daily NIOSH REL.

\subsection{Rifle Shooting}

Gunfire from pistols, rifles, and shotguns produces peak sound levels of $~ 135-175 \mathrm{~dB}(\mathrm{~A})$ [102], typically exceeding the NIOSH and OSHA limit of $140 \mathrm{~dB}(\mathrm{~A})$ for impulse noise, which is an especially dangerous noise type [193]. In a classic study, Taylor and Williams [194] compared the audiograms of 103 middle-aged sports hunters to age-matched controls and found that the hunters had $30-40 \mathrm{~dB}$ worse thresholds at $3-6 \mathrm{kHz}$ in the left ear. In the right ear, which had been partially acoustically shielded by shouldering the gun on the right side, the thresholds were only 10-20 dB worse. If the partial shielding of the right ear with the stock of a gun was enough to prevent much of the apparent NIHL, it almost certainly could have been prevented entirely had the hunters worn suitable hearing protection (Section 4). In a more recent study, Stewart et al. [195] reported a similarly high incidence of hearing loss in waterfowl hunters and a high prevalence of tinnitus; $88 \%$ of hunters were aware that firearm use could cause hearing loss and tinnitus, but many still chose not to use hearing protection while shooting.

Stewart et al. [196] studied the hearing of 210 young (10-17-year-olds) recreational firearm users and found that while most had clinically normal conventional audiograms, $10 \%$ reported chronic tinnitus and $45 \%$ transient tinnitus after shooting. Most kids (81\%) were aware that shooting could result in hearing loss and that hearing protection should 
be used, but only $56 \%$ reported using it consistently during practice shooting, and only $16 \%$ while hunting.

\section{Preventing Noise-Induced Hearing Loss}

As mentioned in Section 2, lifetime noise exposure at the NIOSH REL (85 dB(A); $3 \mathrm{~dB}$ exchange; $40 \mathrm{~h}$ /week) and OSHA PEL (90 dB(A); $5 \mathrm{~dB}$ exchange; $40 \mathrm{~h} /$ week) is estimated to cause "material hearing impairment" ( $1-4 \mathrm{kHz}$ PTA $\geq 25 \mathrm{~dB} \mathrm{HL})$ in $8 \%$ and $25 \%$ of workers, respectively $[17,34]$. Many more people whose conventional audiograms remain better than $25 \mathrm{~dB}$ HL develop other symptoms of NIHL, including difficulties understanding speech, especially in background noise, and chronic tinnitus and hyperacusis $[40-53,197]$. As shown in Section 3, loud music and leisure noise doses often exceed NIOSH and even OSHA limits, putting workers of concert venues, nightclubs, and sports stadiums, as well as the attending public, at considerable risk of NIHL.

While conventional audiometry fails to capture the true extent of NIHL and its associated problems, it appears that even audiometrically-measured hearing loss in young people is on the rise. Shargorodsky et al. [198] analyzed the large-scale U.S. National Health and Nutrition Examination Survey and found that the prevalence of all-cause hearing loss in teenagers increased from $14.9 \%$ in 1994 to $19.5 \%$ in 2006 . Hearing loss was categorized by either a low-frequency $(0.5,1,2 \mathrm{kHz})$ or, more commonly, by a high-frequency $(3,4$, $6,8 \mathrm{kHz}$ ) PTA that exceeded $15 \mathrm{~dB}$ HL in one or both ears [198]. Using the same criteria, the prevalence of hearing loss in Korean teens in 2016 was about 17\% [199]. Although some have questioned the use of this 15 dB HL PTA cutoff [200], Shargorodsky et al. [198] reported that the prevalence of more severe hearing loss (PTA $>25 \mathrm{~dB}$ HL) in U.S. teens also increased, from $3.5 \%$ in 1994 to $5.3 \%$ in 2006. It seems likely that repeated exposure to loud music and leisure noise is a major reason for this increase.

A complicating factor in establishing safe noise exposure limits is the large difference in susceptibility to NIHL between individuals [201,202]. Males are more susceptible than females, not just because they are generally exposed to more noise but because the hormone estrogen (expressed in higher levels in females) is otoprotective [203]. Melanin is also otoprotective, so people with fair skin and eyes are more susceptible to NIHL than those with dark skin and eyes [204-206], as are people with diabetes [207], Bell's palsy (who lack an acoustic reflex) [208], and those with more efficient outer and middle ears [209,210]. Common genetic mutations associated with cochlear antioxidant defense systems can also increase vulnerability to NIHL [211-213]. For example, Chinese factory workers were at higher risk for NIHL when they carried a point mutation in the mitochondrial Mn-superoxide dismutase gene [212], compromising their ability to effectively neutralize mitochondria-generated superoxide, which is toxic to cochlear hair cells if not scavenged rapidly [211]. Finally, although the risk for permanent damage to cochlear hair cells and nerve fibers increases with the amount of TTS induced by a given noise dose, TTS is not a strong predictor of PTS at specific frequencies in individual ears [201,202,214,215].

Recent analyses have recommended that exposures to leisure noise not exceed an 8-h TWA level of $80 \mathrm{~dB}(\mathrm{~A})$, with a $3 \mathrm{~dB}$ exchange [68,69] (Figure 1). Under these guidelines, a two-hour concert should be enjoyed at a level no greater than $86 \mathrm{~dB}(\mathrm{~A})$, assuming that is the only dose of loud sound for the day. Numerous smartphone apps, some free and most others available for just a few dollars, can be used to accurately track sound levels, especially when they are calibrated with a sound level meter. This author has recorded sustained sound levels in the potentially hazardous $85-105 \mathrm{~dB}(\mathrm{~A})$ range at dozens of school dances and talent shows, amateur sports competitions, outdoor car and bike shows, bars and clubs, and in many other common recreational settings. Quite simply, we should build and use quieter machines, turn down the volume to reasonable levels ( $80 \mathrm{~dB}(\mathrm{~A})$ or lower), and shun louder exposures whenever possible. Music and noise loud enough to induce tinnitus, no matter how temporary, should be avoided, although further research is needed to confirm that transient tinnitus is a reliable indicator of permanent (if for a time 
hidden) hearing loss. When avoidance is not possible, as in the symphony orchestra pit, for example, the use of hearing protection should be strongly advised if not mandated.

Even cheap foam earplugs are often sufficient to attenuate excessively loud music and noise down to safer levels, although foam plugs distort sound by providing much more attenuation at high compared to low frequencies. For as little as \$5-10 USD per pair, "musician's earplugs" provide much more uniform attenuation across frequency, allowing for nearly distortion-free listening, and for some people, even improved speech understanding in loud background noise [216-218]. Another option is an active noisecanceling headphone [219-221]. Stage musicians can protect their ears while improving their ability to hear their music by wearing "in-ear monitors", which are Bluetoothed to the amplification system [222]. Double hearing protection, typically consisting of foam earplugs worn under over-the-ear muffs, should be used in the loudest environments, when average 8-h exposures exceed $100 \mathrm{~dB}(\mathrm{~A})$, and when impulse noise exceeds $140 \mathrm{~dB}$ pe $\mathrm{SPL}$, as when shooting guns $[17,223]$.

Despite the many good options for protecting the ear from excessively loud music and noise, usage in non-work environments remains low, especially among young people [224-230]. Some of the stigma associated with earplug use can be attributed to ignorance or lack of concern about NIHL. Raising awareness at an early age should be a priority, yet despite decades of efforts [231-247] (Table 1), basic information to promote hearing conservation remains absent from most school curricula. Hearing conservation should be given similar attention and resources to those allocated for other school health education programs, such as anti-smoking/drug/alcohol programs or sexually transmitted disease and teen pregnancy programs. Some school boards screen children for hearing impairments and such screening could be expanded to include EHF audiometry and DPOAEs, establishing more sensitive baselines for the early detection of future NIHL.

Table 1. Organizations advocating for hearing conservation.

\begin{tabular}{|c|c|}
\hline Name of Organization Advocating for Hearing Conservation & Web Address \\
\hline Academy of Doctors of Audiology & audiologist.org * \\
\hline Action on Hearing Loss & actiononhearingloss.org.uk* \\
\hline American Academy of Audiology & audiology.org * \\
\hline American Academy of Otolaryngology-Head and Neck Surgery & entnet.org * \\
\hline American Speech-Language-Hearing Association & asha.org * \\
\hline American Tinnitus Association & ata.org * \\
\hline Center for Hearing and Communication & chchearing.org * \\
\hline Dangerous Decibels & dangerousdecibels.org * \\
\hline Hearing Education and Awareness for Rockers & hearnet.com * \\
\hline Hearing Industries Association & hearing.org * \\
\hline Hearing Loss Association of America & hearingloss.org * \\
\hline Howard Leight & howardleight.com * \\
\hline National Hearing Conservation Association & hearingconservation.org * \\
\hline National Institute for Occupational Safety and Health & cdc.gov/niosh/topics/noise/* \\
\hline National Institute on Deafness and Other Communication Disorders & nidcd.nih.gov * \\
\hline Sight \& Hearing Association & sightandhearing.org * \\
\hline The Hearing Conservation Workshop & heartomorrow.org * \\
\hline The Noise Pollution Clearinghouse & nonoise.org * \\
\hline The Quiet Coalition & thequietcoalition.org * \\
\hline
\end{tabular}

* Accessed on 15 April 2021.

NIHL is currently a permanent disability. A number of pharmacologic interventions to help protect the ear from over-exposure to loud noise appear to be on the horizon, but nothing is FDA-approved yet $[248,249]$. Hearing aids are helpful but do not restore natural hearing ability, and there is currently no cure for tinnitus or hyperacusis [250], nor for bringing back lost cochlear hair cells and nerve fibers [251-253]. NIHL can precipitate depression, social withdrawal, and cognitive decline [254-260], and mild, moderate, and severe hearing loss increases the risk of dementia by 2-, 3- and 5-fold, respectively [261-263]. For many people with hyperacusis, ambient noise levels in restaurants, malls, and on city streets can be intolerably loud. Severe tinnitus and hyperacusis can drive people to suicide [264]. 
The seemingly indomitable Yul Brynner, like so many others before and since, publicly lamented his chain-smoking habit prior to his untimely death of lung cancer. Like smoking and lung cancer, NIHL is highly prevalent, has far-reaching consequences, and is largely preventable. The relatively recent smoking bans in many indoor and outdoor public spaces represent major public health victories that the hearing field should emulate. While more basic and epidemiological research into safe vs. unsafe noise levels is needed (a notable gap in the literature described in Section 3 is the hearing status of athletes and other employees of loud sports stadiums), there is no reason to further delay the adoption of noise limits in a much broader range of settings than just the factory floor and to neglect educating young people about the potential dangers of frequent exposure to loud music and leisure noise.

Funding: This research received no external funding.

Institutional Review Board Statement: Not applicable.

Informed Consent Statement: Not applicable.

Data Availability Statement: Not applicable.

Conflicts of Interest: The author declares no conflict of interest.

\section{References}

1. Gilbert, D.J. Influence of industrial noises. J. Ind. Hyg. 1922, 3, 264-275.

2. Bunch, C.C. The diagnosis of occupational or traumatic deafness; A historical and audiometric study. Laryngoscope 1937, 47, 615-691.

3. Taylor, W.; Pearson, J.; Mair, A.; Burns, W. Study of noise and hearing in jute weaving. J. Acoust. Soc. Am. 1965, 38, 113-120. [CrossRef] [PubMed]

4. Zhao, F.; Manchaiah, V.K.; French, D.; Price, S.M. Music exposure and hearing disorders: An overview. Int. J. Audiol. 2010, 49, 54-64. [CrossRef]

5. Le Prell, C.G.; Henderson, D.; Fay, R.R.; Popper, A.N. Noise Induced Hearing Loss: Scientific Advances. In Springer Handbook of Auditory Research; Springer: New York, NY, USA, 2012.

6. Thurston, F.E. The worker's ear: A history of noise-induced hearing loss. Am. J. Ind. Med. 2013, 56, 367-377. [CrossRef]

7. Conroy, K.; Malik, V. Hearing loss in the trenches-a hidden morbidity of World War I. J. Laryngol. Otol. 2018, 132, 952-955. [CrossRef]

8. Owen, D. Volume Control: Hearing in a Deafening World; Riverhead Books: New York, NY, USA, 2019.

9. Ampel, F.J.; Uzzle, T. The history of audio and sound measurement. Pro Audio Encyclopedia. 2015. Available online: http: / / proaudioencyclopedia.com/the-history-of-audio-and-sound-measurement/ (accessed on 15 April 2021).

10. Davis, H.; Morgan, C.T.; Hawkins, J.E.; Galambos, R.; Smith, F.W. Final report on temporary deafness following exposure to loud tones and noise. Acta Otolaryngologica 1950, 38, 1-88.

11. Kryter, K.D.; Ward, W.D.; Miller, J.D.; Eldredge, D.H. Hazardous Exposures to Intermittent and Steady-State Noise. J. Acoust. Soc. Am. 1966, 39, 451-464. [CrossRef]

12. Burns, W.; Robinson, D.W. Hearing and Noise in Industry; Her Majesty's Stationery Office: London, UK, 1970.

13. Passchier-Vermeer, W. Hearing loss due to continuous exposure to steady-state broad-band noise. J. Acoust. Soc. Am. 1974, 56, 1585-1593. [CrossRef] [PubMed]

14. National Institute for Occupational Safety and Health (NIOSH). Criteria for a Recommended Standard: Occupational Exposure to Noise; DHHS (NIOSH) Publication No. 73-11001; NIOSH: Washington, DC, USA, 1972.

15. Energy Protection Agency (EPA). Information on Levels of Environmental Noise Requisite to Protect Public Health and Welfare with an Adequate Margin of Safety; Office of Noise Abatement and Control, Environmental Protection Agency: Washington, DC. USA, 1974.

16. Occupational Safety and Health Administration (OSHA). Occupational noise exposure: Hearing conservation amendment, final rule. Fed. Regist. 1983, 48, 9738-9785.

17. National Institute for Occupational Safety and Health (NIOSH). Revised Criteria for a Recommended Standard: Occupational Exposure to Noise; DHHS (NIOSH) Publication No. 98-126; NIOSH: Washington, DC, USA, 1998.

18. Nelson, D.I.; Nelson, R.Y.; Concha-Barrientos, M.; Fingerhut, M. The global burden of occupational noise-induced hearing loss. Am. J. Ind. Med. 2005, 48, 446-458. [CrossRef]

19. Daniell, W.E.; Swan, S.S.; McDaniel, M.M.; Camp, J.E.; Cohen, M.A.; Stebbins, J.G. Noise exposure and hearing loss prevention programmes after 20 years of regulations in the United States. Occup. Environ. Med. 2006, 63, 343-351. [CrossRef]

20. Tak, S.; Davis, R.; Calvert, G. Exposure to hazardous workplace noise and use of hearing protection devices among US workersNHANES, 1999-2004. Am. J. Ind. Med. 2009, 52, 358-371. [CrossRef]

21. Fuente, A.; Hickson, L. Noise-induced hearing loss in Asia. Int. J. Audiol. 2011, 50, S3-S10. [CrossRef] [PubMed]

22. Yankaskas, K. Prelude: Noise-induced tinnitus and hearing loss in the military. Hear. Res. 2013, 295, 3-8. [CrossRef] 
23. Masterson, E.A.; Tak, S.; Themann, C.L.; Wall, D.K.; Groenewold, M.R.; Deddens, J.A.; Calvert, G.M. Prevalence of hearing loss in the United States by industry. Am. J. Ind. Med. 2013, 56, 670-681. [CrossRef]

24. Basner, M.; Babisch, W.; Davis, A.; Brink, M.; Clark, C.; Janssen, S.; Stansfeld, S. Auditory and non-auditory effects of noise on health. Lancet 2014, 383, 1325-1332. [CrossRef]

25. Masterson, E.A.; Sweeney, M.H.; Deddens, J.A.; Themann, C.L.; Wall, D.K. Prevalence of workers with shifts in hearing by industry: A comparison of OSHA and NIOSH Hearing Shift Criteria. J. Occup. Environ. Med. 2014, 56, 446-455. [CrossRef]

26. Masterson, E.A.; Deddens, J.A.; Themann, C.L.; Bertke, S.; Calvert, G.M. Trends in worker hearing loss by industry sector, 1981-2010. Am. J. Ind. Med. 2015, 58, 392-401. [CrossRef]

27. Alamgir, H.; Tucker, D.L.; Kim, S.-Y.; Betancourt, J.; Turner, C.; Gorrell, N.S.; Wong, N.J.; Sagiraju, H.K.R.; Cooper, S.P.; Douphrate, D.I.; et al. Economic burden of hearing loss for the U. S. Military: A proposed framework for estimation. Mil. Med. 2016, 181, 301-306. [CrossRef] [PubMed]

28. Lie, A.; Skogstad, M.; Johannessen, H.A.; Tynes, T.; Mehlum, I.S.; Nordby, K.C.; Engdahl, B.; Tambs, K. Occupational noise exposure and hearing: A systematic review. Int. Arch. Occup. Environ. Health 2016, 89, 351-372. [CrossRef] [PubMed]

29. Swan, A.A.; Nelson, J.T.; Swiger, B.; Jaramillo, C.A.; Eapen, B.C.; Packer, M.; Pugh, M.J. Prevalence of hearing loss and tinnitus in Iraq and Afghanistan Veterans: A Chronic Effects of Neurotrauma Consortium study. Hear. Res. 2017, 349, 4-12. [CrossRef]

30. World Health Organization (WHO). Global Costs of Unaddressed Hearing Loss and Cost-Effectiveness of Interventions; World Health Organization: Geneva, Switzerland, 2017.

31. Wilson, B.S.; Tucci, D.L.; Merson, M.H.; O’Donoghue, G.M. Global hearing health care: New findings and perspectives. Lancet 2017, 390, 2503-2515. [CrossRef]

32. Kerns, E.; Masterson, E.A.; Themann, C.L.; Calvert, G.M. Cardiovascular conditions, hearing difficulty, and occupational noise exposure within US industries and occupations. Am. J. Ind. Med. 2018, 61, 477-491. [CrossRef] [PubMed]

33. Graydon, K.; Waterworth, C.; Miller, H.; Gunasekera, H. Global burden of hearing impairment and ear disease. J. Laryngol. Otol. 2019, 133, 18-25. [CrossRef] [PubMed]

34. Themann, C.L.; Masterson, E.A. Occupational noise exposure: A review of its effects, epidemiology, and impact with recommendations for reducing its burden. J. Acoust. Soc. Am. 2019, 146, 3879-3905. [CrossRef]

35. Barlow, C.; Castilla-Sanchez, F. Occupational noise exposure and regulatory adherence in music venues in the United Kingdom. Noise Health 2012, 14, 86-90. [CrossRef]

36. Fosbroke, J. Practical observations on the pathology and treatment of deafness. Lancet 1830, 15, 645-648. [CrossRef]

37. Chung, D.Y.; Gannon, R.P.; Mason, K. Factors affecting the prevalence of tinnitus. Audiology 1984, 23, 441-452. [CrossRef]

38. Nondahl, D.M.; Cruickshanks, K.J.; Huang, G.-H.; Klein, B.E.; Klein, R.; Nieto, F.J.; Tweed, T.S. Tinnitus and its risk factors in the Beaver Dam Offspring Study. Int. J. Audiol. 2011, 50, 313-320. [CrossRef]

39. Bhatt, J.M.; Lin, H.W.; Bhattacharyya, N. Prevalence, severity, exposures, and treatment patterns of tinnitus in the United States. JAMA Otolaryngol. Head Neck Surg. 2016, 142, 959-965. [CrossRef]

40. Barnea, G.; Attias, J.; Gold, S.; Shahar, A. Tinnitus with normal hearing sensitivity: Extended high-frequency audiometry and auditory-nerve brain-stem-evoked responses. Audiology 1990, 29, 36-45. [CrossRef] [PubMed]

41. Davis, A.C.; Lovell, E.A.; Smith, P.A.; Ferguson, M.A. The contribution of social noise to tinnitus in young people-A preliminary report. Noise Health 1998, 1, 40-46.

42. Griest, S.E.; Bishop, P.M. Tinnitus as an early indicator of permanent hearing loss. A 15 year longitudinal study of noise exposed workers. Workplace Health Safety J. 1998, 46, 325-329.

43. Holgers, K.M.; Pettersson, B. Noise exposure and subjective hearing symptoms among school children in Sweden. Noise Health 2005, 7, 27-37. [CrossRef]

44. Sanchez, T.G.; Medeiros, I.R.; Levy, C.P.; Ramalho Jda, R.; Bento, R.F. Tinnitus in normally hearing patients: Clinical aspects and repercussions. Braz. J. Otorhinolaryngol. 2005, 71, 427-431. [CrossRef]

45. Hind, S.E.; Haines-Bazrafshan, R.; Benton, C.L.; Brassington, W.; Towle, B.; Moore, D.R. Prevalence of clinical referrals having hearing thresholds within normal limits. Int. J. Audiol. 2011, 50, 708-716. [CrossRef]

46. Kumar, U.A.; Ameenudin, S.; Sangamanatha, A.V. Temporal and speech processing skills in normal hearing individuals exposed to occupational noise. Noise Health 2012, 14, 100-105.

47. Beach, E.F.; Williams, W.; Gilliver, M. Estimating young Australian adults' risk of hearing damage from selected leisure activities. Ear. Hear. 2013, 34, 75-82. [CrossRef]

48. Tung, C.-Y.; Chao, K.-P. Effect of recreational noise exposure on hearing impairment among teenage students. Res. Dev. Disab. 2013, 34, 126-132. [CrossRef] [PubMed]

49. Sheldrake, J.; Diehl, P.U.; Schaette, R. Audiometric characteristics of hyperacusis patients. Front. Neurol. 2015, 6, 105. [CrossRef]

50. Tremblay, K.L.; Pinto, A.; Fischer, M.E.; Klein, B.E.; Klein, R.; Levy, S.; Tweed, T.S.; Cruickshanks, K.J. Self-Reported Hearing Difficulties Among Adults With Normal Audiograms: The Beaver Dam Offspring Study. Ear. Hear. 2015, 36, 290-299. [CrossRef]

51. Guest, H.; Munro, K.J.; Prendergast, G.; Howe, S.; Plack, C.J. Tinnitus with a normal audiogram: Relation to noise exposure but no evidence for cochlear synaptopathy. Hear. Res. 2017, 344, 265-274. [CrossRef]

52. Moore, D.R.; Zobay, O.; Mackinnon, R.C.; Whitmer, W.M.; Akeroyd, M.A. Lifetime leisure music exposure associated with increased frequency of tinnitus. Hear. Res. 2017, 347, 18-27. [CrossRef] [PubMed] 
53. Parthasarathy, A.; Hancock, K.E.; Bennett, K.; DeGruttola, V.; Polley, D.B. Bottom-up and top-down neural signatures of disordered multi-talker speech perception in adults with normal hearing. Elife 2020, 9, e51419. [CrossRef]

54. Clark, W.W.; Bohne, B.A.; Boettcher, F.A. Effect of periodic rest on hearing loss and cochlear damage following exposure to noise. J. Acoust. Soc. Am. 1987, 82, 1253-1264. [CrossRef]

55. Subramaniam, M.; Salvi, R.J.; Spongr, V.P.; Henderson, D.; Powers, N.L. Changes in distortion product otoacoustic emissions and outer hair cells following interrupted noise exposures. Hear. Res. 1994, 74, 204-216. [CrossRef]

56. Withnell, R.H. The cochlear microphonic as an indication of outer hair cell function. Ear. Hear. 2001, 22, 75-77. [CrossRef]

57. Chen, G.D.; Fechter, L.D. The relationship between noise-induced hearing loss and hair cell loss in rats. Hear. Res. 2003, 177, 81-90. [CrossRef]

58. Schuknecht, H.F.; Woellner, R.C. Hearing losses following partial section of the cochlear nerve. Laryngoscope 1953, 63, 441-465. [CrossRef]

59. Kujawa, S.G.; Liberman, M.C. Adding insult to injury: Cochlear nerve degeneration after "temporary" noise-induced hearing loss. J. Neurosci. 2009, 29, 14077-14085. [CrossRef]

60. Lin, H.W.; Furman, A.C.; Kujawa, S.G.; Liberman, M.C. Primary neural degeneration in the guinea pig cochlea after reversible noise-induced threshold shift. J. Assoc. Res. Otolaryngol. 2011, 12, 605-616. [CrossRef]

61. Wang, Y.; Ren, C. Effects of repeated "benign" noise exposures in young CBA mice: Shedding light on age-related hearing loss. J. Assoc. Res. Otolaryngol. 2012, 13, 505-515. [CrossRef]

62. Lobarinas, E.; Salvi, R.; Ding, D. Insensitivity of the audiogram to carboplatin induced inner hair cell loss in chinchillas. Hear Res 2013, 302, 113-120. [CrossRef]

63. Chambers, A.R.; Resnik, J.; Yuan, Y.; Whitton, J.P.; Edge, A.S.; Liberman, M.C.; Polley, D.B. Central gain restores auditory processing following near-complete cochlear denervation. Neuron 2016, 89, 867-879. [CrossRef]

64. Pienkowski, M. On the etiology of listening difficulties in noise despite clinically normal audiograms. Ear Hear. 2017, 38, 135-148. [CrossRef]

65. Welch, D.; Fremaux, G. Why Do People Like Loud Sound? A Qualitative Study. Int. J. Environ. Res. Public Health 2017, 14, 908. [CrossRef] [PubMed]

66. Chung, J.H.; Des Roches, C.M.; Meunier, J.; Eavey, R.D. Evaluation of noise-induced hearing loss in young people using a web-based survey technique. Pediatrics 2005, 115, 861-867. [CrossRef]

67. Jones, P. Tinnitus: Warning for Music Fans Attending Concerts. BBC Wales News, 12 July 2019. Available online: https://www.bbc com/news/uk-wales-47948065?fbclid=IwAR3SLyZXar1ol2SBT-AO-usqSMCiaF_zpB5j7d3Qx8b31niLCtu8gMg-HCg(accessed on 15 April 2021).

68. Neitzel, R.L.; Fligor, B.J. Risk of noise-induced hearing loss due to recreational sound: Review and recommendations. J. Acoust. Soc. Am. 2019, 146, 3911-3921. [CrossRef] [PubMed]

69. Roberts, B.; Neitzel, R.L. Noise exposure limit for children in recreational settings: Review of available evidence. J. Acoust. Soc. Am. 2019, 146, 3922-3933. [CrossRef]

70. Moore, B.C.J. A review of the perceptual effects of hearing loss for frequencies above $3 \mathrm{kHz}$. Int. J. Audiol. 2016, 55, 707-714. [CrossRef]

71. Hunter, L.L.; Monson, B.B.; Moore, D.R.; Dhar, S.; Wright, B.A.; Munro, K.J.; Zadeh, L.M.; Blankenship, C.M.; Stiepan, S.M.; Siegel, J.H. Extended High Frequency Hearing and Speech Perception Implications in Adults and Children. Hear. Res. 2020, $397,107922$. [CrossRef] [PubMed]

72. Johnson, D.; Nixon, C.; Stephenson, M. Long-duration exposure to intermittent noises. Aviat. Space Environ. Med. 1976, 47, 987-990. [PubMed]

73. Ward, E.D.; Cushing, E.M.; Burns, E.M. Effective quiet and moderate TTS: Implications for noise exposure standards. J. Acoust. Soc. Am. 1976, 59, 160-165. [CrossRef]

74. Nixon, C.; Johnson, D.; Stephenson, M. Asymptotic behavior of temporary threshold shift and recovery from 24 to 48 hour noise exposures. Aviat. Space Environ. Med. 1977, 48, 311-515.

75. World Health Organization (WHO). Guidelines for Community Noise; World Health Organization: Geneva, Switzerland, 1999.

76. Neitzel, R.L.; Gershon, R.R.M.; McAlexander, T.P.; Magda, L.A.; Pearson, J.M. Exposures to transit and other sources of noise among New York City residents. Environ. Sci. Technol. 2012, 46, 500-508. [CrossRef]

77. McAlexander, T.P.; Gershon, R.R.M.; Neitzel, R.L. Streetlevel noise in an urban setting: Assessment and contribution to personal exposure. Environ. Health 2015, 14, 1-10. [CrossRef] [PubMed]

78. Basner, M.; Brink, M.; Bristow, A.; de Kluizenaar, Y.; Finegold, L.; Hong, J. ICBEN review of research on the biological effects of noise 2011-2014. Noise Health 2015, 17, 57-82. [CrossRef] [PubMed]

79. Neitzel, R.L.; Seixas, N.; Goldman, B.; Daniell, W. Contributions of non-occupational activities to total noise exposure of construction workers. Ann. Occup. Hyg. 2004, 48, 463-473.

80. Abbate, C.; Concetto, G.; Fortunato, M.; Brecciaroli, R.; Tringali, M.A.; Beninato, G.; D'Arrigo, G.; Domenico, G. Influence of environmental factors on the evolution of industrial noise-induced hearing loss. Environ. Monit. Assess. 2005, 107, 351-361. [CrossRef]

81. Jokitulppo, J.; Toivonen, M.; Björk, E. Estimated leisure-time noise exposure, hearing thresholds, and hearing symptoms of Finnish conscripts. Mil. Med. 2006, 171, 112-116. [CrossRef] 
82. Leensen, M.C.; van Duivenbooden, J.C.; Dreschler, W.A. A retrospective analysis of noise-induced hearing loss in the Dutch construction industry. Int. Arch. Occup. Environ. Health 2011, 84, 577-590. [CrossRef]

83. Feder, K.; Marro, L.; McNamee, J.; Michaud, D. Prevalence of loud leisure noise activities among a representative sample of Canadians aged 6-79 years. J. Acoust. Soc. Am. 2019, 146, 3934-3946. [CrossRef]

84. International Standards Organization (ISO). ISO Standard 1999; Acoustics-determination of occupational noise exposure and estimation of noise-induced hearing impairment; International Standards Organization: Geneve, Switzerland, 1990.

85. Johnson, D.L.; Papadopoulos, P.; Watfa, N.; Takala, J. Exposure criteria, occupational exposure levels. In Occupational Exposure to Noise: Evaluation, Prevention and Control; WHO: Geneva, Switzerland, 2001; pp. 79-102.

86. European Union (EU). Directive 2003/10/EC of the European Parliament and of the Council of 6 February 2003 on the Minimum Health and Safety Requirements Regarding the Exposure of Workers to the Risks Arising from Physical Agents (Noise); EU: Brussels, Belgium, 2003.

87. Arenas, J.P.; Suter, A.H. Comparison of occupational noise legislation in the Americas: An overview and analysis. Noise Health 2014, 16, 306-319. [CrossRef] [PubMed]

88. Kerr, M.J.; Neitzel, R.L.; Hong, O.; Sataloff, R.T. Historical review of efforts to reduce noise-induced hearing loss in the United States. Am. J. Ind. Med. 2017, 60, 569-577. [CrossRef]

89. Beach, E.F.; Gilliver, M.; Williams, W. Leisure noise exposure: Participation trends, symptoms of hearing damage, and perception of risk. Int. J. Audiol. 2013, 52 (Suppl. 1), 20-25. [CrossRef] [PubMed]

90. Williams, W.; Beach, E.F.; Gilliver, M. Clubbing: The cumulative effect of noise exposure from attendance at dance clubs and night clubs on whole-of-life noise exposure. Noise Health 2010, 12, 155-158. [CrossRef] [PubMed]

91. Flamme, G.A.; Stephenson, M.R.; Deiters, K.; Tatro, A.; van Gessel, D.; Geda, K.; Wyllys, K.; McGregor, K. Typical noise exposure in daily life. Int. J. Audiol. 2012, 51 (Suppl. 1), 3-11. [CrossRef]

92. Jokitulppo, J.S.; Björk, E.A.; Akaan-Penttilä, E. Estimated leisure noise exposure and hearing symptoms in Finnish teenagers. Scand. Audiol. 1997, 26, 257-262. [CrossRef] [PubMed]

93. Biassoni, E.C.; Serra, M.R.; Richtert, U.; Joekes, S.; Yacci, M.R.; Carignani, J.A.; Abraham, S.; Minoldo, G.; Franco, G. Recreational noise exposure and its effects on the hearing of adolescents. Part II: Development of hearing disorders. Int. J. Audiol. 2005, 44, 74-85. [CrossRef]

94. Vogel, I.; Verschuure, H.; van der Ploeg, C.P.; Brug, J.; Raat, H. Estimating adolescent risk for hearing loss based on data from a large school-based survey. Am. J. Public Health 2010, 100, 1095-1100. [CrossRef]

95. Henderson, E.; Testa, M.A.; Hartnick, C. Prevalence of noise-induced hearing-threshold shifts and hearing loss among US youths. Pediatrics 2011, 127, 39-46. [CrossRef]

96. Gilles, A.; De Ridder, D.; Van Hal, G.; Wouters, K.; Kleine Punte, A.; Van de Heyning, P. Prevalence of leisure noise-induced tinnitus and the attitude toward noise in university students. Otol. Neurotol. 2012, 33, 899-906. [CrossRef]

97. Gilles, A.; Van Hal, G.; De Ridder, D.; Wouters, K.; Van de Heyning, P. Epidemiology of noise-induced tinnitus and the attitudes and beliefs towards noise and hearing protection in adolescents. PLoS ONE 2013, 8, e70297. [CrossRef]

98. Johnson, O.; Andrew, B.; Walker, D.; Morgan, S.; Aldren, A. British university students' attitudes towards noise-induced hearing loss caused by nightclub attendance. J. Laryngol. Otol. 2014, 128, 29-34. [CrossRef] [PubMed]

99. Vogel, I.; van de Looij-Jansen, P.M.; Mieloo, C.L.; Burdorf, A.; de Waart, F. Risky music listening, permanent tinnitus and depression, anxiety, thoughts about suicide and adverse general health. PLoS ONE 2014, 9, e98912. [CrossRef]

100. Dehnert, K.; Raab, U.; Perez-Alvarez, C.; Steffens, T.; Bolte, G.; Fromme, H.; Twardella, D. Total leisure noise exposure and its association with hearing loss among adolescents. Int. J. Audiol. 2015, 54, 665-673. [CrossRef]

101. World Health Organization (WHO). Hearing Loss due to Recreational Exposure to Loud Sounds; A review; World Health Organization: Geneva, Switzerland, 2015.

102. Speaks, C.; Nelson, D.; Ward, W.D. Hearing loss in rock-and-roll musicians. J. Occup. Environ. Med. 1970, 12, 216-219. [CrossRef] [PubMed]

103. Clark, W.W. Noise exposure from leisure activities: A review. J. Acoust. Soc. Am. 1991, 90, 175-181. [CrossRef] [PubMed]

104. Meyer-Bisch, C. Epidemiological evaluation of hearing damage related to strongly amplified music (personal cassette players, discotheques, rock concerts)-High-definition audiometric survey on 1364 subjects. Audiology 1996, 35, 121-142. [CrossRef] [PubMed]

105. Gunderson, E.; Moline, J.; Catalano, P. Risks of developing noise-induced hearing loss in employees of urban music clubs. Am. J. Ind. Med. 1997, 31, 75-79. [CrossRef]

106. Opperman, D.A.; Reifman, W.; Schlauch, R.; Levine, S. Incidence of spontaneous hearing threshold shifts during modern concert performances. Otolaryngol. Head. Neck. Surg. 2006, 134, 667-673. [CrossRef] [PubMed]

107. Grose, J.H.; Buss, E.; Hall, J.W., 3rd. Loud music exposure and cochlear synaptopathy in young adults: Isolated auditory brainstem response effects but no perceptual consequences. Trends. Hear. 2017, 21, 2331216517737417.

108. Le Prell, C.G.; Dell, S.; Hensley, B.N.; Hall, J.W.I.; Campbell, K.C.M.; Antonelli, P.A.; Green, G.E.; Miller, J.M.; Guire, K. Digital music exposure reliably induces temporary threshold shift (TTS) in normal hearing human subjects. Ear. Hear. 2012, $33,44-58$. [CrossRef] [PubMed]

109. Bogoch, I.I.; House, R.A.; Kudla, I. Perceptions about hearing protection and noise-induced hearing loss of attendees of rock concerts. Can. J. Public Health 2005, 96, 69-72. [CrossRef]

110. Axelsson, A.; Lindgren, F. Hearing in classical musicians. Acta. Otolaryngol. 1981, 91, 3-74. [CrossRef] 
111. Axelsson, A.; Eliasson, A.; Israelsson, B. Hearing in pop/rock musicians: A follow-up study. Ear. Hear. 1995, 16, $245-253$. [CrossRef]

112. Kähäri, K.R.; Zachau, G.; Eklöf, M.; Sandsjö, L.; Möller, C. Assessment of hearing and hearing disorders in rock/jazz musicians. Int. J. Audiol. 2003, 42, 279-288. [CrossRef]

113. Juman, S.; Karmody, C.S.; Simeon, D. Hearing loss in steelband musicians. Otolaryngol. Head. Neck Surg. 2003, 131, 461-465. [CrossRef] [PubMed]

114. Schmuziger, N.J.; Patscheke, J.; Probst, R. Hearing in non-professional pop/rock musicians. Ear. Hear. 2006, 27, 321-330. [CrossRef] [PubMed]

115. Størmer, C.C.; Laukli, E.; Høydal, E.H.; Stenklev, N.C. Hearing loss and tinnitus in rock musicians: A Norwegian survey. Noise Health 2015, 17, 411-421. [CrossRef] [PubMed]

116. McIlvaine, D.; Stewart, M.; Anderson, R. Noise exposure levels for musicians during rehearsal and performance times. Med. Probl. Perform. Art. 2012, 27, 31-36. [CrossRef]

117. Jansson, E.; Karlsson, K. Sound levels recorded within the symphony orchestra and risk criteria for hearing loss. Scand. Audiol. 1983, 12, 215-221. [CrossRef] [PubMed]

118. Royster, J.D.; Royster, L.H.; Killion, M.C. Sound exposures and hearing thresholds of symphony orchestra musicians. J. Acoust. Soc. Am. 1991, 89, 2793-2803. [CrossRef] [PubMed]

119. Lee, J.; Behar, A.; Kunov, H.; Wong, W. Musicians' noise exposure in orchestra pit. Appl. Acoust. 2005, 66, 919-931. [CrossRef]

120. Emmerich, E.; Rudel, L.; Richter, F. Is the audiologic status of professional musicians a reflection of the noise exposure in classical orchestral music? Eur. Arch. Otorhinolaryngol. 2008, 265, 753-758. [CrossRef] [PubMed]

121. Kang, T.S.; Lee, L.K.; Kang, S.C.; Yoon, C.S.; Park, D.U.; Kim, R.H. Assessment of noise measurements made with a continuous monitoring in time. J. Acoust. Soc. Am. 2010, 134, 822-831. [CrossRef] [PubMed]

122. O'Brien, I.; Driscoll, T.; Ackermann, B. Sound Exposure of Professional Orchestral Musicians during Solitary Practice. J. Acoust. Soc. Am. 2013, 134, 2748-2754. [CrossRef] [PubMed]

123. Karlsson, K.; Lundquist, P.G.; Olaussen, T. The hearing of symphony orchestra musicians. Scand. Audiol. 1983, 12, 257-264. [CrossRef] [PubMed]

124. Strasser, H.; Irle, H.; Scholz, R. Physiological cost of energy-equivalent exposures to white noise, industrial noise, heavy metal music, and classical music. Noise Control Eng. J. 1999, 47, 187-192. [CrossRef]

125. Strasser, H.; Irle, H.; Legler, R. Temporary hearing threshold shifts and restitution after energy-equivalent exposures to industrial noise and classical music. Noise Health 2003, 5, 75-84.

126. Swanson, S.J.; Dengerink, H.A.; Kondrick, P.; Miller, C.L. The influence of subjective factors on temporary threshold shifts after exposure to music and noise of equal energy. Ear. Hear. 1987, 8, 288-291. [CrossRef] [PubMed]

127. Axelsson, A.; Lindgren, F. Does pop music cause hearing damage? Audiology 1977, 16, 432-437. [CrossRef] [PubMed]

128. Westmore, G.A.; Eversden, I.D. Noise-induced hearing loss and orchestral musicians. Arch. Otolaryngol. 1981, 107, 761-764. [CrossRef] [PubMed]

129. Ostri, B.; Eller, N.; Dahlin, E.; Skylv, G. Hearing impairment in orchestral musicians. Scand. Audiol. 1989, 18, 243-249. [CrossRef] [PubMed]

130. Kähäri, K.R.; Axelsson, A.; Hellström, P.A.; Zachau, G. Hearing assessment of classical orchestral musicians. Scand. Audiol. 2001, 30, 13-23. [CrossRef]

131. Kähäri, K.R.; Axelsson, A.; Hellström, P.A.; Zachau, G. Hearing development in classical orchestral musicians. A follow-up study. Scand. Audiol. 2001, 30, 141-149. [CrossRef]

132. Laitinen, H.M.; Toppila, E.M.; Olkinuora, P.S.; Kuisma, K. Sound exposure among the Finnish National Opera personnel. Appl. Occup. Environ. Hyg. 2003, 18, 177-182. [CrossRef]

133. Jansen, E.J.M.; Helleman, H.W.; Dreschler, W.A.; Laat, J.A.P.M. Noise induced hearing loss and other hearing complaints among musicians of symphony orchestras. Int. Arch. Occ. Environ. Health 2009, 82, 153-164. [CrossRef]

134. Phillips, S.L.; Henrich, V.C.; Mace, S.T. Prevalence of noise-induced hearing loss in student musicians. Int. J. Audiol. 2010, 49, 309-316. [CrossRef] [PubMed]

135. Toppila, E.; Koskinen, H.; Pyykko, I. Hearing loss among classical-orchestra musicians. Noise Health 2011, 13, 45-50. [CrossRef] [PubMed]

136. Schmidt, J.H.; Pedersen, E.; Paarup, H.; Christensen-Dalsgaard, J.; Andersen, T.; Poulsen, T.; Baelum, J. Hearing Loss in Relation to Sound Exposure of Professional Symphony Orchestra Musicians. Ear. Hear. 2014, 35, 448-460. [CrossRef] [PubMed]

137. Halevi-Katz, D.N.; Yaakobi, E.; Putter-Katz, H. Exposure to music and noise-induced hearing loss (NIHL) among professional pop/rock/jazz musicians. Noise Health 2015, 17, 158-164. [CrossRef]

138. Pawalczyk-Luszczynska, M.; Zamojska-Daniszewska, M.; Dudarewicz, A.; Zaborowski, K. Exposure to excessive sounds and hearing status in academic classical music students. Int. J. Occup. Med. Environ. Health 2017, 30, 55-75.

139. Pouryaghoub, G.; Mehrdad, R.; Pourhosein, S. Noise-Induced hearing loss among professional musicians. J. Occup. Health 2017, 59, 33-37. [CrossRef] [PubMed]

140. Schmidt, J.H.; Paarup, H.M.; Baelum, J. Tinnitus severity is related to the sound exposure of symphony orchestra musicians independently of hearing impairment. Ear. Hear. 2019, 40, 88-97. [CrossRef] [PubMed] 
141. Kazkayasi, M.; Yetiser, S.; Ozcelik, S. Effect of musical training on musical perception and hearing sensitivity: Conventional and high-frequency audiometric comparison. J. Otolaryngol. 2006, 35, 343-348. [CrossRef] [PubMed]

142. Liberman, M.C.; Epstein, M.J.; Cleveland, S.S.; Wang, H.; Maison, S.F. Toward a Differential Diagnosis of Hidden Hearing Loss in Humans. PLoS ONE 2016, 11, e0162726. [CrossRef] [PubMed]

143. Schmuziger, N.; Patscheke, J.; Probst, R. An assessment of threshold shifts in nonprofessional pop/rock musicians using conventional and extended high-frequency audiometry. Ear. Hear. 2007, 28, 643-648. [CrossRef]

144. Keefe, J. Noise Exposure Associated with Marching and Pep Bands. ASA/NOISE-CON. 2005. Available online: http://acoustics. org/pressroom/httpdocs/150th/Keefe.html (accessed on 15 April 2021).

145. National Institute for Occupational Safety and Health (NIOSH). Health Hazard Evaluation Report: Noise Evaluation of Elementary and High School Music Classes and Indoor Marching Band Rehearsals-Alabama; Publication No. 2011-0129-3160; Chen, L., Brueck, S., Eds.; NIOSH: Washington, DC, USA, 2012.

146. Russell, J.A.; Yamaguchi, M. Sound Exposure of Healthcare Professionals Working With a University Marching Band. J. Am. Acad. Audiol. 2018, 29, 83-89. [CrossRef]

147. Jin, S.H.; Nelson, P.B.; Schlauch, R.; Carney, E. Hearing conservation program for marching band members: A risk for noiseinduced hearing loss? Am. J. Audiol. 2013, 22, 26-39. [CrossRef]

148. Di Stadio, A.; Dipietro, L.; Ricci, G.; Della Volpe, A.; Minni, A.; Greco, A.; de Vincentiis, M.; Ralli, M. Hearing Loss, Tinnitus, Hyperacusis, and Diplacusis in Professional Musicians: A Systematic Review. Int. J. Environ. Res. Public. Health. 2018, 15, E2120. [CrossRef] [PubMed]

149. Gundersen, E. List of Rockers with Hearing Loss Grows. 2018. Available online: https://www.aarp.org/health/conditionstreatments/info-2018/musicians-hearing-loss.html(accessed on 15 April 2021).

150. Coleman, C. Royal Opera House Loses Appeal over Viola Player's Hearing. British Broadcasting Corporation Wales News, 12 July 2019. Available online: https://www.bbc.com/news/entertainment-arts-47965734(accessed on 15 April 2021).

151. Tan, T.C.; Tsang, H.C.; Wong, T.L. Noise surveys in discotheques in Hong Kong. Ind. Health 1990, 28, 37-40. [PubMed]

152. Lee, L.T. A study of the noise hazard to employees in local discotheques]. Singapore Med. J. 1999, 40, 571-574.

153. Sadhra, S.; Jackson, C.A.; Ryder, T.; Brown, M.J. Noise exposure and hearing loss among student employees working in university entertainment venues. Ann. Occup. Hyg. 2002, 46, 455-463.

154. Park, M.-Y. Assessment of potential noise-induced hearing loss with commercial "Karaoke" noise. Int. J. Ind. Ergonom. 2003, 31, 375-385. [CrossRef]

155. Bray, A.; Szymański, M.; Mills, R. Noise induced hearing loss in dance music disc jockeys and an examination of sound levels in nightclubs. J. Laryngol. Otol. 2004, 118, 123-128. [CrossRef] [PubMed]

156. Twardella, D.; Wellhoefer, A.; Brix, J.; Fromme, H. High sound pressure levels in Bavarian discotheques remain after introduction of voluntary agreements. Noise Health 2008, 10, 99-104. [CrossRef] [PubMed]

157. Kelly, A.C.; Boyd, S.M.; Henehan, G.T.; Chambers, G. Occupational noise exposure of nightclub bar employees in Ireland. Noise Health 2012, 14, 148-154. [CrossRef]

158. Potier, M.; Hoquet, C.; Lloyd, R.; Nicolas-Puel, C.; Uziel, A.; Puel, J.L. The risks of amplified music for disc-jockeys working in nightclubs. Ear. Hear. 2009, 30, 291-293. [CrossRef]

159. Serra, M.R.; Biassoni, E.C.; Richter, U.; Minoldo, G.; Franco, G.; Abraham, S.; Carignani, J.A.; Joekes, S.; Yacci, M.R. Recreational noise exposure and its effects on the hearing of adolescents. Part I: An interdisciplinary long-term study. Int. J. Audiol. 2005, 44, 65-73. [CrossRef]

160. Biassoni, E.C.; Serra, M.R.; Hinalaf, M.; Abraham, M.; Pavlik, M.; Villalobo, J.P.; Curet, C.; Joekes, S.; Yacci, M.R.; Righetti, A. Hearing and loud music exposure in a group of adolescents at the ages of 14-15 and retested at 17-18. Noise Health 2014, 16, 331-341. [CrossRef] [PubMed]

161. Serra, M.R.; Biassoni, E.C.; Hinalaf, M.; Abraham, M.; Pavlik, M.; Villalobo, J.P.; Curet, C.; Joekes, S.; Yacci, M.R.; Righetti, A. Hearing and loud music exposure in 14-15 years old adolescents. Noise Health 2014, 16, 320-330. [CrossRef] [PubMed]

162. Keith, S.E.; Michaud, D.S.; Chiu, V. Evaluating the maximum playback sound levels from portable digital audio players. J. Acoust. Soc. Am. 2008, 123, 4227-4237. [CrossRef]

163. Breinbauer, H.A.; Anabalón, J.L.; Gutierrez, D.; Cárcamo, R.; Olivares, C.; Caro, J. Output capabilities of personal music players and assessment of preferred listening levels of test subjects: Outlining recommendations for preventing music-induced hearing loss. Laryngoscope 2012, 122, 2549-2556. [CrossRef]

164. Shim, H.; Lee, S.; Koo, M.; Kim, J. Analysis of Output Levels of an MP3 Player: Effects of Earphone Type, Music Genre, and Listening Duration. J. Audiol. Otol. 2018, 22, 140-147. [CrossRef]

165. Jiang, W.; Zhao, F.; Guderley, N.; Manchaiah, V. Daily music exposure dose and hearing problems using personal listening devices in adolescents and young adults: A systematic review. Int. J. Audiol. 2016, 55, 197-205. [CrossRef]

166. Fligor, B.J.; Levey, S.; Levey, T. Cultural and demographic factors influencing noise exposure estimates from use of portable listening devices in an urban environment. J. Speech Lang. Hear. Res. 2013, 57, 1535-1547. [CrossRef] [PubMed]

167. Levey, S.; Levey, T.; Fligor, B.J. Noise exposure estimates of urban MP3 player users. J. Speech Lang. Hear. Res. 2011, 54, $263-277$. [CrossRef]

168. Gilliver, M.; Nguyen, J.; Beach, E.F.; Barr, C. Personal Listening Devices in Australia: Patterns of Use and Levels of Risk. Semin. Hear. 2017, 38, 282-297. [PubMed] 
169. Muchnik, C.; Amir, N.; Shabtai, E.; Kaplan-Neeman, R. Preferred listening levels of personal listening devices in young teenagers: Self reports and physical measurements. Int. J. Audiol. 2012, 51, 287-293. [CrossRef]

170. Cone, B.K.; Wake, M.; Tobin, S.; Poulakis, Z.; Rickards, F.W. Slight-mild sensorineural hearing loss in children: Audiometric, clinical, and risk factor profiles. Ear. Hear. 2010, 31, 202-212. [CrossRef]

171. Båsjö, S.; Möller, C.; Widén, S.; Jutengren, G.; Kähäri, K. Hearing thresholds, tinnitus, and headphone listening habits in nine-year-old children. Int. J. Audiol. 2016, 55, 587-596. [CrossRef]

172. Mills, J.H. Noise and children: A review of literature. J. Acoust. Soc. Am. 1975, 58, 767-779. [CrossRef] [PubMed]

173. Mahboubi, H.; Oliaei, S.; Badran, K.W. Systematic assessment of noise amplitude generated by toys intended for young children. Otolaryngol. Head Neck Surg. 2013, 148, 1043-1047. [CrossRef] [PubMed]

174. Peng, J.H.; Tao, Z.Z.; Huang, Z.W. Risk of damage to hearing from personal listening devices in young adults. J. Otolaryngol. 2007, 36, 181-185. [CrossRef] [PubMed]

175. Le Prell, C.G.; Spankovich, C.; Lobarinas, E.; Griffiths, S.K. Extended high-frequency thresholds in college students: Effects of music player use and other recreational noise. J. Am. Acad. Audiol. 2013, 24, 725-739. [CrossRef]

176. Sulaiman, A.H.; Husain, R.; Seluakumaran, K. Evaluation of early hearing damage in personal listening device users using extended high-frequency audiometry and otoacoustic emissions. Eur. Arch. Otorhinolaryngol. 2014, 271, 1463-1470. [CrossRef] [PubMed]

177. Engard, D.J.; Sandfort, D.R.; Gotshall, R.W.; Brazile, W.J. Noise exposure, characterization, and comparison of three football stadiums. J. Occup. Environ. Hyg. 2010, 7, 616-621. [CrossRef]

178. Hodgetts, W.E.; Liu, R. Can hockey playoffs harm your hearing? CMAJ 2006, 175, 1541-1542. [CrossRef]

179. Cranston, C.J.; Brazile, W.J.; Sandfort, D.R.; Gotshall, R.W. Occupational and recreational noise exposure from indoor arena hockey games. J. Occup. Environ. Hyg. 2013, 10, 11-16. [CrossRef] [PubMed]

180. De Swanepoel, W.; Hall, J.W., 3rd. Football match spectator sound exposure and effect on hearing: A pretest-post-test study. S. Afr. Med. J. 2010, 100, 239-242. [CrossRef]

181. Flamme, G.A.; Williams, N. Sports officials' hearing status: Whistle use as a factor contributing to hearing trouble. J. Occup. Environ. Hyg. 2013, 10, 1-10. [CrossRef]

182. Torre, P., 3rd; Howell, J.C. Noise levels during aerobics and the potential effects on distortion product otoacoustic emissions. J. Commun. Disord. 2008, 41, 501-511. [CrossRef] [PubMed]

183. Nassar, G. The human temporary threshold shift after exposure to 60 minutes' noise in an aerobics class. Br. J. Audiol. 2001, 35, 99-101. [CrossRef]

184. Beach, E.F.; Nie, V. Noise levels in fitness classes are still too high: Evidence from 1997-1998 and 2009-2011. Arch. Environ. Occup. Health 2014, 69, 223-230. [CrossRef] [PubMed]

185. Rose, A.S.; Ebert, C.S., Jr.; Prazma, J.; Pillsbury, H.C., 3rd. Noise exposure levels in stock car auto racing. Ear Nose Throat J. 2008, 87, 689-692. [CrossRef] [PubMed]

186. Kardous, C.; Morata, T. Occupational and recreational noise exposures at stock car racing circuits: An exploratory survey of three professional race tracks. Noise Control Eng. 2010, 58, 54-61. [CrossRef]

187. Morley, J.C.; Seitz, T.; Tubbs, R. Carbon monoxide and noise exposure at a monster truck and motocross show. Appl. Occup. Environ. Hyg. 1999, 14, 645-655. [CrossRef]

188. McCombe, A.W.; Binnington, J. Hearing loss in Grand Prix motorcyclists: Occupational hazard or sports injury? Br. J. Sports Med. 1994, 28, 35-37. [CrossRef]

189. Ross, B.C. Noise exposure of motorcyclists. Ann. Occup. Hyg. 1989, 33, 123-127. [PubMed]

190. Kennedy, J.; Carley, M.; Walker, I.; Holt, N. On-road and wind-tunnel measurement of motorcycle helmet noise. J. Acoust. Soc. Am. 2013, 134, 2004-2010. [CrossRef] [PubMed]

191. McCombe, A.W.; Binington, J.; Davis, A.C.; Spencer, H. Hearing loss in motorcyclists. J. Laryngol. Otol. 1995, 109, 599-604. [CrossRef]

192. Moore, K.L. Noise Exposures of Recreational Snowmobilers. University of Colorado Unpublished Thesis. 2014. Available online: https:/ / digscholarship.unco.edu/cgi/viewcontent.cgi?article=1002\&context=capstones (accessed on 15 April 2021).

193. Zhao, Y.M.; Qiu, W.; Zeng, L.; Chen, S.S.; Cheng, X.R.; Davis, R.I.; Hamernik, R.P. Application of the kurtosis statistic to the evaluation of the risk of hearing loss in workers exposed to high-level complex noise. Ear. Hear. 2010, 31, 527-532. [CrossRef] [PubMed]

194. Taylor, C.D.; Williams, E. Acoustic trauma in the sports hunter. Laryngoscope 1966, 76, 863-879. [CrossRef]

195. Stewart, M.; Borer, S.E.; Lehman, M. Shooting habits of U.S. waterfowl hunters. Noise Health 2009, 11, 8-13. [CrossRef] [PubMed]

196. Stewart, M.; Meinke, D.K.; Snyders, J.K.; Howerton, K. Shooting habits of youth recreational firearm users. Int. J. Audiol. 2014, 53, 26-34. [CrossRef]

197. Zadeh, L.M.; Silbert, N.H.; Sternasty, K.; Swanepoel, D.W.; Hunter, L.L.; Moore, D.R. Extended high-frequency hearing enhances speech perception in noise. PNAS 2019, 116, 23753-23759. [CrossRef] [PubMed]

198. Shargorodsky, J.; Curhan, S.G.; Curhan, G.C.; Eavey, R. Change in prevalence of hearing loss in US adolescents. JAMA 2010, 304, 772-778. [CrossRef]

199. Rhee, J.; Lee, D.; Lim, H.J.; Park, M.K.; Suh, M.W.; Lee, J.H.; Hong, Y.C.; Oh, S.H. Hearing loss in Korean adolescents: The prevalence thereof and its association with leisure noise exposure. PLoS ONE 2019, 14, e0209254. [CrossRef] [PubMed] 
200. Schlauch, R.S.; Carney, E. The challenge of detecting minimal hearing loss in audiometric surveys. Am. J. Audiol. 2012, 21, 106-119. [CrossRef]

201. Ward, W.D. The concept of susceptibility to hearing loss. J. Occup. Med. 1965, 7, 595-607. [CrossRef] [PubMed]

202. Henderson, D.; Subramaniam, M.; Boettcher, F.A. Individual susceptibility to noise-induced hearing loss: An old topic revisited. Ear. Hear. 1993, 14, 152-168. [CrossRef] [PubMed]

203. Shuster, B.Z.; Depireux, D.A.; Mong, J.A.; Hertzano, R. Sex differences in hearing: Probing the role of estrogen signaling. J. Acoust. Soc. Am. 2019, 145, 3656-3663. [CrossRef] [PubMed]

204. Da Costa, E.A.; Castro, J.C.; Macedo, M.E. Iris pigmentation and susceptibility to noise-induced hearing loss. Int. J. Audiol. 2008, 47, 115-118. [CrossRef] [PubMed]

205. Flamme, G.A.; Deiters, K.; Needham, T. Distributions of pure-tone hearing threshold levels among adolescents and adults in the United States by gender, ethnicity, and age: Results from the US National Health and Nutrition Examination Survey. Int. J. Audiol. 2011, 50, S11-S20. [CrossRef] [PubMed]

206. Lin, F.R.; Maas, P.; Chien, W.; Carey, J.P.; Ferrucci, L.; Thorpe, R. Association of skin color, race/ethnicity, and hearing loss among adults in the USA. J. Assoc. Res. Otolaryngol. 2012, 13, 109-117. [CrossRef] [PubMed]

207. Spankovich, C.; Le Prell, C.G.; Lobarinas, E.; Hood, L.J. Noise History and Auditory Function in Young Adults With and Without Type 1 Diabetes Mellitus. Ear. Hear. 2017, 38, 724-735. [CrossRef] [PubMed]

208. Zakrisson, J.E.; Borg, E.; Lidén, G.; Nilsson, R. Stapedius reflex in industrial impact noise: Fatigability and role for temporary threshold shift (TTS). Scand. Audiol. Suppl. 1980, 12, 326-334.

209. Shotland, L.I. Dosimetry measurements using a probe tube microphone in the ear canal. J. Acoust. Soc. Am. 1996, 99, 979-984. [CrossRef]

210. Grinn, S.K.; Le Prell, C.G. Noise-dose estimated with and without pre-cochlear amplification. J. Acoust. Soc. Am. 2019, $146,3967$. [CrossRef] [PubMed]

211. Henderson, D.; Bielefeld, E.C.; Harris, K.C. The role of oxidative stress in noise-induced hearing loss. Ear. Hear. 2006, $27,1-19$. [CrossRef]

212. Liu, Y.-M.; Li, X.-D.; Guo, X.; Liu, B.; Lin, A.-H.; Ding, Y.-L.; Rao, S.-Q. SOD2 V16A SNP in the mitochondrial targeting sequence is associated with noise induced hearing loss in Chinese workers. Dis. Markers 2010, 28, 137-147. [CrossRef]

213. Sliwinska-Kowalska, M.; Pawelczyk, M. Contribution of genetic factors to noise-induced hearing loss: A human studies review. Mutat. Res. 2013, 752, 61-65. [CrossRef] [PubMed]

214. Nordmann, A.S.; Bohne, B.A.; Harding, G.W. Histopathological differences between temporary and permanent threshold shift. Hear. Res. 2000, 139, 13-30. [CrossRef]

215. Fernandez, K.A.; Jeffers, P.W.; Lall, K.; Liberman, M.C.; Kujawa, S.G. Aging after noise exposure: Acceleration of cochlear synaptopathy in "recovered" ears. J. Neurosci. 2015, 35, 7509-7520. [CrossRef] [PubMed]

216. Beach, E.; Williams, W.; Gilliver, M. Hearing protection for clubbers is music to their ears. Health Promot. J. Aust. 2010, $21,215-221$. [CrossRef]

217. Themann, C.L.; Suter, A.H.; Stephenson, M.R. National research agenda for the prevention of occupational hearing loss-Part 1. Sem. Hear. 2013, 34, 145-207. [CrossRef]

218. Hickey, K. Musician Earplugs: Knowledge, Attitudes, Beliefs, Behaviors, and Experiences among Small Music Venue Workers; Capstones \& Scholarly Projects. 67. 2019. Available online: https://digscholarship.unco.edu/capstones/67 (accessed on 15 April 2021).

219. Brown, C.H.; Gordon, M.S. Motorcycle Helmet Noise and Active Noise Reduction. Open Acoust. J. 2011, 4, 14-24. [CrossRef]

220. Henry, P.; Foots, A. Comparison of user volume control settings for portable music players with three earphone configurations in quiet and noisy environments. J. Am. Acad. Audiol. 2012, 23, 182-191. [CrossRef] [PubMed]

221. Liang, M.J.; Zhao, F.; French, D.; Zheng, Y.Q. Characteristics of noise-canceling headphones to reduce the hearing hazard for MP3 users. J. Acoust. Soc. Am. 2012, 131, 4526-4534. [CrossRef]

222. Chasin, M. Musicians and the Prevention of Hearing Loss; Singular Press: San Diego, CA, USA, 2010.

223. Murphy, W.J.; Byrne, D.C.; Franks, J.R. Firearms and hearing protection. Hear. Rev. 2007, 14, $36-38$.

224. Widén, S.E.; Erlandsson, S.I. The influence of socio-economic status on adolescent attitude to social noise and hearing protection. Noise Health 2004, 7, 59-70. [PubMed]

225. Laitinen, H.M. Factors affecting the use of hearing protectors among classical music players. Noise Health 2005, 7, 21-29. [CrossRef] [PubMed]

226. Nondahl, D.M.; Cruickshanks, K.J.; Dalton, D.S.; Klein, B.E.; Klein, R.; Tweed, T.S.; Wiley, T.L. The use of hearing protection devices by older adults during recreational noise exposure. Noise Health 2006, 8, 147-153. [CrossRef] [PubMed]

227. Huttunen, K.; Sivonen, V.; Poykko, V. Symphony orchestra musicians' use of hearing protection and attenuation of custom-made hearing protectors as measured with two different real-ear attenuation at threshold methods. Noise Health 2011, 13, 176-188. [CrossRef] [PubMed]

228. Beach, E.F.; Williams, W.; Gilliver, M. A qualitative study of earplug use as a health behavior: The role of noise injury symptoms, self-efficacy and an affinity for music. J. Health Psych. 2012, 17, 237-246. [CrossRef] [PubMed]

229. Beach, E.F.; O'Brien, I. In Their Own Words: Interviews with Musicians Reveal the Advantages and Disadvantages of Wearing Earplugs. Med. Probl. Perform. Art. 2017, 32, 101-110. [CrossRef] 
230. Hunter, A. Attitudes, risk behavior, and noise exposure among young adults with hearing problems: Identifying a typology. Semin. Hear. 2017, 38, 332-347. [CrossRef] [PubMed]

231. Cozad, R.L.; Marston, L.; Joseph, D. Some implications regarding high frequency hearing loss in school-age children. J. School Health 1974, 44, 92-96. [CrossRef]

232. Lass, N.J.; Woodford, C.M.; Lundeen, C.; Lundeen, D.J.; Everly-Myer, D.S. A survey of high school students' knowledge and awareness of hearing, hearing loss, and hearing health. Hear. J. 1987, 40, 15-19.

233. Lass, N.J.; Woodford, C.M.; Lundeen, C.; Lundeen, D.J.; Everly-Myer, D.S.; McGuire, K.; Mason, D.S.; Paknik, L.; Phillips, R.P. A hearing-conservation program for a junior high school. Hear. J. 1987, 40, 32-40.

234. Lewis, D.A. A hearing conservation program for high school-level students. Hear. J. 1989, 42, 19-24.

235. Chermak, G.D.; Peters-McCarthy, E. The effectiveness of an educational hearing conservation program for elementary school children. Lang. Speech Hear. Serv. Sch. 1991, 22, 308-312. [CrossRef]

236. Blair, J.C.; Hardegree, D.; Benson, P.V. Necessity and effectiveness of a hearing conservation program for elementary students. J. Edu. Audiol. 1996, 4, 12-16.

237. Chermak, G.D.; Curtis, L.; Seikel, J.A. The effectiveness of an interactive hearing conservation program for elementary school children. Lang. Speech Hear. Serv. Sch. 1996, 27, 29-39. [CrossRef]

238. Knobloch, M.J.; Broste, S.K. A hearing conservation program for Wisconsin youth working in agriculture. J. Sch. Health 1998, 68, 313-318. [CrossRef]

239. Lukes, E.; Johnson, M. Hearing conservation: Community outreach programs for high school students. Am. Assoc. Occ. Health Nurses J. 1998, 46, 340-343. [CrossRef]

240. Anderson, K.L. Hearing conservation in the public schools revisited. Sem. Hear. 1999, 12, 340-364. [CrossRef]

241. Bennett, J.A.; English, K. Teaching hearing conservation to school children: Comparing the outcomes and efficacy of two pedagogical approaches. J. Edu. Audiol. 1999, 7, 29-33.

242. Folmer, R.L.; Griest, S.E.; Martin, W.H. Hearing conservation education programs for children: A review. J. Sch. Health 2002, 72, 51-57. [CrossRef]

243. Folmer, R.L. The importance of hearing conservation instruction. J. Sch. Nurs. 2003, 19, 140-148. [CrossRef] [PubMed]

244. Fausti, S.A.; Wilmington, D.J.; Helt, P.V.; Helt, W.J.; Konrad-Martin, D. Hearing health and care: The need for improved hearing loss prevention and hearing conservation practices. J. Rehabil. Res. Dev. 2005, 42, 45-62. [CrossRef] [PubMed]

245. Marlenga, B.; Linneman, J.G.; Pickett, W.; Wood, D.J.; Kirkhorn, S.R.; Broste, S.K. Randomized trial of a hearing conservation intervention for rural students: Long-term outcomes. Pediatrics 2011, 128, 1139-1146. [CrossRef] [PubMed]

246. Auchter, M.; Le Prell, C.G. Hearing loss prevention education using adopt-a-band: Changes in self-reported earplug use in two high school marching bands. Am. J. Audiol. 2014, 23, 211-226. [CrossRef] [PubMed]

247. Gilles, A.; Paul Vde, H. Effectiveness of a preventive campaign for noise-induced hearing damage in adolescents. Int. J. Pediatr. Otorhinolaryngol. 2014, 78, 604-609. [CrossRef]

248. Sha, S.H.; Schacht, J. Emerging therapeutic interventions against noise-induced hearing loss. Expert Opin. Investig. Drugs 2017, 26, 85-96. [CrossRef] [PubMed]

249. Bielefeld, E.C.; Harrison, R.T.; Riley DeBacker, J. Pharmaceutical otoprotection strategies to prevent impulse noise-induced hearing loss. J. Acoust. Soc. Am. 2019, 146, 3790. [CrossRef]

250. McFerran, D.J.; Stockdale, D.; Holme, R.; Large, C.H.; Baguley, D.M. Why Is There No Cure for Tinnitus? Front. Neurosci. 2019, 13, 802. [CrossRef] [PubMed]

251. Bielefeld, E.C.; Kobel, M.J. Advances and Challenges in Pharmaceutical Therapies to Prevent and Repair Cochlear Injuries From Noise. Front. Cell Neurosci. 2019, 13, 285. [CrossRef] [PubMed]

252. Kujawa, S.G.; Liberman, M.C. Translating animal models to human therapeutics in noise-induced and age-related hearing loss. Hear. Res. 2019, 377, 44-52. [CrossRef] [PubMed]

253. Schilder, A.G.M.; Su, M.P.; Mandavia, R.; Anderson, C.R.; Landry, E.; Ferdous, T.; Blackshaw, H. Early phase trials of novel hearing therapeutics: Avenues and opportunities. Hear. Res. 2019, 380, 175-186. [CrossRef]

254. Kraus, K.S.; Mitra, S.; Jimenez, Z.; Hinduja, S.; Ding, D.; Jiang, H.; Gray, L.; Lobarinas, E.; Sun, W.; Salvi, R.J. Noise trauma impairs neurogenesis in the rat hippocampus. Neuroscience 2010, 167, 1216-1226. [CrossRef] [PubMed]

255. Li, C.M.; Zhang, X.; Hoffman, H.J.; Cotch, M.F.; Themann, C.L.; Wilson, M.R. Hearing impairment associated with depression in US adults, National Health and Nutrition Examination Survey 2005-2010. JAMA Otolaryngol. Head. Neck Surg. 2014, 140, $293-302$. [CrossRef] [PubMed]

256. Martini, A.; Castiglione, A.; Bovo, R.; Vallesi, A.; Gabelli, C. Aging, cognitive load, dementia and hearing loss. Audiol. Neurotol. 2014, 19, 2-5. [CrossRef]

257. Dawes, P.; Emsley, R.; Cruickshanks, K.J.; Moore, D.R.; Fortnum, H.; Edmondson-Jones, M.; McCormack, A.; Munro, K.J. Hearing loss and cognition: The role of hearing aids, social isolation and depression. PLoS ONE 2015, 10, e0119616. [CrossRef]

258. Fortunato, S.; Forli, F.; Guglielmi, V.; De Corso, E.; Paludetti, G.; Berrettini, S.; Fetoni, A.R. A review of new insights on the association between hearing loss and cognitive decline in ageing. Acta. Otorhinolaryngol. Ital. 2016, 36, 155-166. [CrossRef] [PubMed]

259. Liu, L.; Shen, P.; He, T.; Chang, Y.; Shi, L.; Tao, S.; Li, X.; Xun, Q.; Guo, X.; Yu, Z.; et al. Noise induced hearing loss impairs spatial learning/memory and hippocampal neurogenesis in mice. Sci. Rep. 2016, 6, 20374. [CrossRef] [PubMed] 
260. Cosh, S.; Carriere, I.; Daien, V.; Amieva, H.; Tzourio, C.; Delcourt, C.; Helmer, C. The relationship between hearing loss in older adults and depression over 12 years: Findings from the three-year prospective cohort study. Int. J. Geriatr. Psychiat. 2018, 33, 1654-1661. [CrossRef] [PubMed]

261. Lin, F.R.; Metter, E.J.; O’Brien, R.J.; Resnick, S.M.; Zonderman, A.B.; Ferrucci, L. Hearing loss and incident dementia. Arch. Neurol. 2011, 68, 214-220. [CrossRef] [PubMed]

262. Livingston, G.; Sommerlad, A.; Orgeta, V.; Costafreda, S.G.; Huntley, J.; Ames, D.; Ballard, C. Dementia prevention, intervention, and care. Lancet 2017, 390, 2673-2734. [CrossRef]

263. Thomson, R.S.; Auduong, P.; Miller, A.T.; Gurgel, R.K. Hearing loss as a risk factor for dementia: A systematic review. Laryngoscope Investig. Otolaryngol. 2017, 2, 69-79. [CrossRef] [PubMed]

264. Aazh, H.; Moore, B.C.J. Thoughts about Suicide and Self-Harm in Patients with Tinnitus and Hyperacusis. J. Am. Acad. Adiol. 2018, 29, 255-261. [CrossRef] [PubMed] 